\title{
Nutritive evaluation of foliage from fodder trees and shrubs characteristic of Algerian arid and semi-arid areas* $^{*}$
}

\author{
L. Bouazza ${ }^{1,2}$, R. Bodas ${ }^{1}$, S. Boufennara ${ }^{1,2}$, H. Bousseboua ${ }^{2}$ \\ and S. López ${ }^{1,3}$ \\ ${ }^{1}$ University of Leon, Instituto de Ganadería de Montaña (CSIC-ULE), \\ Department of Animal Production \\ E-24071 León, Spain \\ ${ }^{2}$ University Mentouri of Constantine, Department of Applied Microbiology \\ BP 360, route de Ain El-Bey, Algeria
}

(Received 18 November 2011; revised version 28 May 2012; accepted 14 September 2012)

\begin{abstract}
The chemical composition and digestibility of foliage from nine browse plant species (Artemisia herba-alba, Atriplex halimus, Acacia nilotica, Acacia horrida, Acacia saligna, Faidherbia albida, Albizia julibrissin, Vicia faba and Punica granatum) grown in arid and semi-arid areas of Algeria were evaluated. Feed components were determined by proximate analysis, whereas phenolic and tannin compounds were analysed by colorimetric procedures and their activity tested using a biological assay. Digestibility was assessed by conventional gravimetric in vitro and in situ methods, and rumen fermentation kinetics were estimated from the in vitro gas production technique. The foliage from Acacia species was found to be a protein-rich fodder for ruminants, although the high lignin and tannin content of some species is an important constraint limiting its digestive utilization in the gastrointestinal tract. The leguminous fodder tree, A. julibrissin, has a high protein content and its foliage is highly digestible owing to its low tannin content. Foliage from P. granatum is a highly digestible browse for ruminants.
\end{abstract}

KEY WORDS: forage, digestibility, Acacia, browse, plant secondary compounds, tannins

\footnotetext{
* Supported by Junta de Castilla y León, Project GR158

${ }^{3}$ Corresponding author: e-mail: s.lopez@unileon.es
} 


\section{INTRODUCTION}

The north African climate is characterized by extreme fluctuations, such as succession of rainy and dry years, large thermal amplitude during the day, irregular rainfall, long dry seasons, etc. Droughts occur frequently and have a critical influence on vegetation, and thus on rangelands. Arid climates are associated with the reduction or loss of the perennial vegetation cover, an initial stage of land degradation and desertification (Le Houérou, 1992).

The Algerian steppe covers more than 30 million ha of land and constitutes a transition area between the green belt in the North and the Sahara desert. The diversity and relative abundance of fodder plants has allowed the steppe to provide animal food for $15 \%$ of the Algerian population, and constitutes the main source of red meat for the population as a whole (Aidoud, 1994). In Algeria, these steppe areas are used mainly for sheep production with local breeds well adapted to the extreme environmental conditions and showing a particular productive performance. Currently, steppe rangelands are in a process of degradation due to the fragility of the physical environment; changes in the nomadic pastoral traditions are accelerating this process (Aidoud, 1994). The increase in the number of livestock and establishment of settled farms have contributed to overgrazing and deterioration of these rangelands. The increasing degradation of rangelands in the steppe zones gives rise to a severe decline in feed supply for herbivores, given the low and declining production of biomass (Le Houérou, 1992).

Acacia and other shrubby plants can be used to mitigate desertification, alleviating the effects of droughts, allowing soil fixation, and enhancing restoration of the vegetation and rehabilitation of rangelands. Trees, especially those of the Acacia genus, are adapted to a low moisture environment. Furthermore, fodder trees and shrub foliage play an important role in ruminant feeding systems in arid areas around the world (Le Houérou, 1989; El Aich, 1992). Acacia leaves and fruits are a potential source of protein, especially when herbaceous vegetation becomes withered during droughts (Osuji and Odenyo, 1997). The rational use of fodder and browse requires accurate information about the nutritive value of these fibrous resources. Along with the information on the nutrient content, the presence of antinutritional compounds is of special interest for this sort of feedstuff, as high concentrations of tannins are found in many browse trees (Dube et al., 2001). These compounds can impair the digestive utilization of the feed ingested by the animal. Biological assays to estimate the rate and extent of ruminal digestion of these fibrous feedstuffs, especially those containing secondary compounds, provide comprehensive information on their potential nutritive value for ruminants. In vitro digestibility procedures and the gas fermentation technique are interesting tools that provide such information (López, 2005), and have also been proposed to assess the biological effect of tannins contained in feedstuffs (Ammar et al., 1999). 
The objective of this study was to investigate the nutritive value of foliage from several Acacia species and other fodder trees grown in arid and semi-arid areas of Algeria, including some common browse species as reference for a comparison (i.e. Atriplex halimus, Vicia faba, Artemisia herba-alba). The study was based on chemical analysis, quantification of tannins by colorimetric and biological assays, and estimation of digestibility by in vitro procedures.

\section{MATERIAL AND METHODS}

\section{Description of the study site}

Plant samples were collected from four Algerian locations: Constantine (N 36 19' 48.32"'- E 6 35' 04.99", 600 m altitude), Djelfa (N 34 39' 63.66"- E

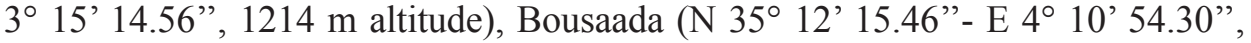
669 m altitude) and M'sila (N 35 43' 25.33"- E 4'33' 24.93”, 490 m altitude). Constantine is in eastern Algeria, in a semi-arid region with a continental climate with erratic annual precipitation of 350-700 $\mathrm{mm}$. Djelfa, Bousaada and M'sila are in north central Algeria in the middle of the steppe rangelands of an arid high plateau. The climate type in these locations is BSh according to the Köppen climate classification and characterized by hot, sometimes extremely hot, summers and mild to warm winters, and a low annual average precipitation between 100 and $300 \mathrm{~mm}$.

\section{Fodder material}

Foliage from nine browse species (Table 1) was collected: Artemisia herba-alba, Atriplex halimus, Acacia nilotica, Acacia horrida, Acacia saligna, Faidherbia albida, Albizia julibrissin, Vicia faba and Punica granatum. Fodder material collected (leaf or aerial), location and season of sampling for each plant species are described in Table 1. African Acacia species are perennial. Selection of the species was based on the available information on their consumption by grazing small ruminants, and on their relative abundance in the area of study. Between six and ten specimens of each plant species were sampled to obtain a representative aliquot of the edible biomass. Leaves were clipped with scissors from the aerial part of the plants, and taken immediately to the laboratory where the samples from the different specimens of the same species were mixed, oven-dried at $50^{\circ} \mathrm{C}$ (Makkar, 2003), and subsequently ground to pass a $1 \mathrm{~mm}$ screen for chemical analysis and $3 \mathrm{~mm}$ for in situ degradability. 


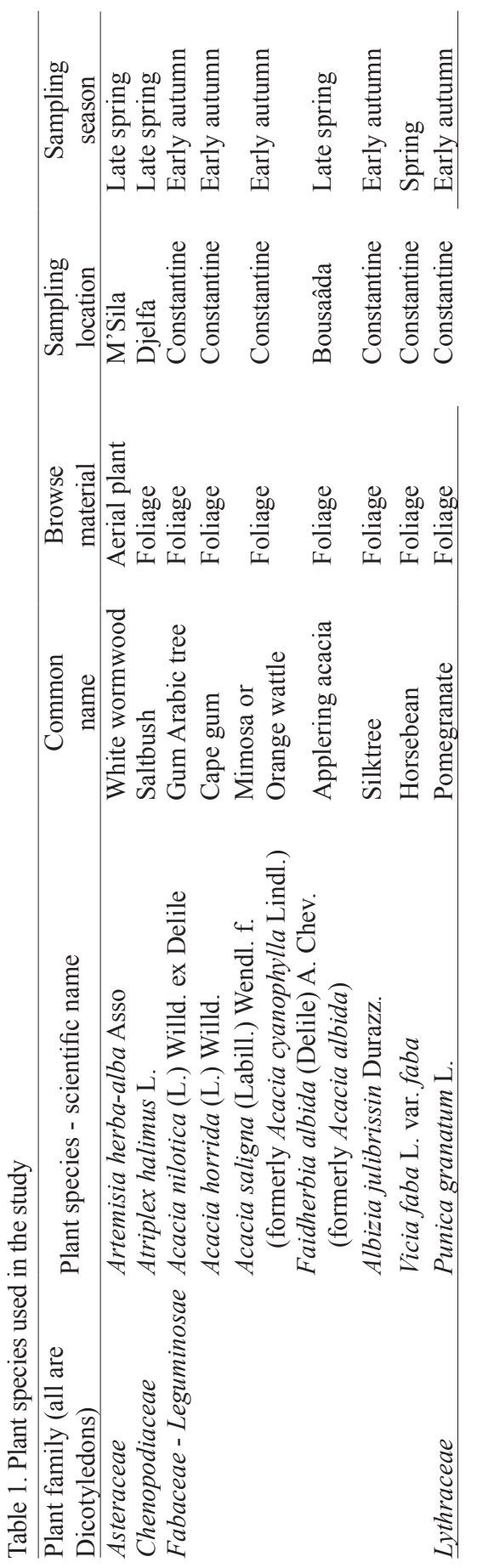




\section{Chemical analysis}

Dry matter (DM), ash and crude protein (CP) contents were determined following the methods of AOAC (2000). Neutral and acid detergent fibre (NDF and ADF, respectively) and sulphuric acid detergent lignin (ADL) were determined using the ANKOM fibre analyser as described by Van Soest et al. (1991). Sodium sulphite, but not $\alpha$-amylase, was added to the solution for the NDF determination. Both fibre fractions were expressed including residual ash.

Phenolic compounds were extracted following the procedures described by Makkar (2003). Total extractable phenols (TEP) were determined using the FolinCiolateau reagent and tannic acid as the standard. Total extractable tannins (TET) were estimated indirectly after adsorption of TEP to insoluble polyvinylpyrrolidone, and measuring the remaining total phenols (or non-precipitable phenols) in the supernatant (Makkar, 2003). The concentration of TET was calculated by difference as TET $=$ TEP - non-precipitable phenols. Free condensed tannins (FCT) were measured in the extract using the butanol- $\mathrm{HCl}$ assay, with the modifications of Makkar (2003) and using purified quebracho tannin as the standard. The bound condensed tannins (BCT) were measured in the solid residue remaining after extraction of phenolic compounds. The concentration of total condensed tannins (TCT) was calculated as TCT $=$ FCT + BCT. The concentrations of phenols and tannins were expressed in $\mathrm{g}$ tannic acid equivalent $/ \mathrm{kg} \mathrm{DM}$, whereas the concentration of condensed tannins was expressed in $g$ quebracho equivalent $/ \mathrm{kg}$ DM. All chemical analyses were performed in triplicate.

\section{Animals and rumen fluid extraction for in vitro and in situ studies}

Four mature Merino sheep (body weight $49.4 \pm 4.23 \mathrm{~kg}$ ) fitted with a permanent ruminal cannula (60 $\mathrm{mm}$ diameter) were used for the extraction of rumen fluid or for in situ incubation of nylon bags. Animals were fed with lucerne hay ad libitum (CP $167 \mathrm{~g}$, NDF $502 \mathrm{~g}$, ADF $355 \mathrm{~g}$ and ADL $71 \mathrm{~g} / \mathrm{kg} \mathrm{DM}$ ) and had free access to water and a mineral/vitamin block. Samples of rumen contents were withdrawn prior to morning feeding, transferred into thermos flasks and taken immediately to the laboratory, where rumen fluid was strained through layers of cheesecloth and kept at $39^{\circ} \mathrm{C}$ under a constant flow of $\mathrm{CO}_{2}$.

\section{In vitro digestibility}

In vitro dry matter digestibility was determined using the ANKOM-DAISY procedure (Ammar et al., 1999) following two different approaches, that described by Tilley and Terry (1963) and the one described by Van Soest (1994). Both techniques were carried out separately in different incubations. 
A culture medium containing macro- and micro-mineral solutions, a bicarbonate buffer solution and resazurin was prepared as described by Ammar et al. (1999). The medium was maintained at $39^{\circ} \mathrm{C}$ and saturated with $\mathrm{CO}_{2}$. Oxygen in the medium was removed by the addition of a reducing solution containing cysteine- $\mathrm{HCl}$ and sodium sulphide. Rumen fluid was then added to the medium at a proportion of 1:4 $(\mathrm{v} / \mathrm{v})$. Samples of plant material $(400 \mathrm{mg})$ were weighed into artificial fibre bags (size $5 \mathrm{~cm} \times 5 \mathrm{~cm}$, pore size $20 \mu \mathrm{m}$ ) that were heat-sealed and placed in incubation jars (5 1 glass receptacles with a plastic lid provided with a one-way valve to avoid the accumulation of fermentation gases). Each incubation jar was filled with 21 of the buffered rumen fluid transferred anaerobically, and closed with the lid, mixing the contents thoroughly. The jars were then placed in a revolving incubator (Ankom Daisy II digestion system, ANKOM Technology Corp., Fairport, NY, USA) at $39^{\circ} \mathrm{C}$, with continuous rotation to ensure the effective immersion of the bags in the rumen fluid. After $48 \mathrm{~h}$ of incubation in buffered rumen fluid, samples were dried to estimate in vitro dry matter loss (IVDMloss) after $48 \mathrm{~h}$ incubation. The bags were then used to measure in vitro digestibility following the original method of Tilley and Terry (1963) subjecting them to $48 \mathrm{~h}$ acid pepsin-HCl digestion, and the dry residue remaining in the bag was considered to be the apparently indigestible $\mathrm{DM}$ for estimation of in vitro digestibility (IVD-TT). The other batch of bags was gently rinsed in cold water followed by extraction with a neutral detergent solution at $100^{\circ} \mathrm{C}$ for $1 \mathrm{~h}$ as described by Van Soest (1994). The extraction with neutral detergent removes bacterial cell walls and other endogenous products, and therefore can be considered a determination of the in vitro true digestibility (TIVD). With each procedure, each browse sample was incubated in quadruplicate, with one bag per sample incubated in each jar and rumen fluid from each of the four sheep incubated separately in each of the four jars.

\section{In vitro gas production kinetics}

Gas production profiles were obtained using an adaptation of the technique described by Theodorou et al. (1994). Ground samples $(500 \mathrm{mg}$ ) were incubated in $50 \mathrm{ml}$ of diluted rumen fluid $(10 \mathrm{ml}$ mixed rumen fluid $+40 \mathrm{ml}$ medium prepared under a $\mathrm{CO}_{2}$ constant flow) in $120 \mathrm{ml}$ serum bottles. Six bottles containing only diluted rumen fluid were incubated as blanks and used to compensate for gas production in the absence of substrate. Once filled up, all of the bottles were closed with rubber stoppers, crimped with aluminium seals, shaken and placed in an incubator at $39^{\circ} \mathrm{C}$. The volume of gas produced was recorded at several incubation times $(3,6,9,12,16,21,26,31,36,48,72,96,120$, and $144 \mathrm{~h}$ after inoculation) using a pressure transducer (Delta Ohm DTP704-2BGI, Herter Instruments SL, Barcelona). At the end of the incubation (after $144 \mathrm{~h}$ ), the contents of each serum bottle were filtered using sintered glass crucibles (coarse porosity no. 1, pore size $100-160 \mu \mathrm{m})$ under vacuum. Then the residue was washed out with a neutral 
detergent solution at $100^{\circ} \mathrm{C}$ for $1 \mathrm{~h}$ and oven-dried at $100^{\circ} \mathrm{C}$ for $48 \mathrm{~h}$ to estimate the potential DM disappearance (D144, g/g DM incubated). Incubations were performed using three different inocula (rumen fluid from three sheep used separately) with two bottles per rumen fluid inoculum (for a total of six observations - three replicates per sample). In order to estimate the fermentation kinetics parameters, gas production data were fitted using the exponential model proposed by France et al. (2000):

$$
G=A\left[1-\mathrm{e}^{-c(t-L)}\right] \text { for } t \geq L
$$

where: $G(\mathrm{ml} / \mathrm{g})$ - the cumulative gas production at time $t ; A(\mathrm{ml} / \mathrm{g})$ - the asymptotic gas production; $c\left(\mathrm{~h}^{-1}\right)$ - the fractional rate of substrate fermentation and $L(\mathrm{~h})$ - the lag time. The volume of gas $(\mathrm{ml} / \mathrm{g} \mathrm{DM})$ produced after $24 \mathrm{~h}$ of incubation (G24) was used as an index of digestibility and energy feed value. According to France et al. (2000), the extent of degradation in the rumen $(E D, \mathrm{~g} / \mathrm{g} \mathrm{DM})$ for a given rate of passage $\left(k, \mathrm{~h}^{-1}\right)$ was estimated as:

$$
E D=\frac{c \times D 144}{c+k} \mathrm{e}^{-k L}
$$

where: $D 144$ - the dry matter disappearance after $144 \mathrm{~h}$ of incubation. To calculate $\mathrm{ED}$, a rate of passage of $0.03 \mathrm{~h}^{-1}$ (characteristic for sheep fed with a forage diet at maintenance level) was used.

\section{Polyethylene glycol (PEG) bio-assay for the assessment of tannins}

The bio-assay for the assessment of the activity of tannins has been described in detail by Ammar et al. (2004). The gas production technique described above was also used for this biological assay. Incubations were carried out in serum bottles with or without the addition of $500 \mathrm{mg}$ PEG. Ground samples (300 mg) were weighed out into serum bottles, kept at approximately $39^{\circ} \mathrm{C}$ and flushed with $\mathrm{CO}_{2}$ before use. Two bottles were used for each substrate with each inoculum source (rumen fluid from three sheep was used separately as three different inocula giving three replicates per treatment), one for each treatment (with or without PEG). The bottles were tightly closed and placed in an incubator at $39^{\circ} \mathrm{C}$, and shaken at regular intervals. The volume of gas produced in each bottle was recorded using a pressure transducer at $6,12,24$ and $48 \mathrm{~h}$ after inoculation. Gas production was corrected by subtracting the volume of gas produced from blank cultures. Tannin activity was calculated as the ratio between cumulative gas measured in the PEG bottle and that recorded in the control (no PEG) bottle for each sample and inoculum. For each sample, values from the three replicates (inoculum sources) were averaged. 
In situ degradability

The procedure to measure in situ disappearance has been described in detail by López et al. (1999). In situ DM degradability in the rumen of each browse species was determined as the DM disappearance when samples (3 $\mathrm{g} \mathrm{DM})$ weighed in nylon bags $(45 \mu \mathrm{m}$ pore size and $7.5 \times 15 \mathrm{~cm}$ size) were incubated for 24 and $96 \mathrm{~h}$ in the rumen of three fistulated Merino sheep fed with lucerne hay ( 3 bags per sample and incubation time, one in each sheep). At the end of incubation, the bags were removed from the rumen, rinsed with cold tap water and washed in a washing machine with cold water for 3 cycles of $3 \mathrm{~min}$ each. The washed bags were dried in a forced draft oven at $100^{\circ} \mathrm{C}$ for $48 \mathrm{~h}$, and the residual DM used to calculate DM disappearance at each incubation time. Two bags per sample were washed following the same procedure without being previously incubated in the rumen to estimate DM disappearance at $0 \mathrm{~h}$ (estimate of DM solubility and particle loss from the bag).

\section{Statistical analysis}

One-way analysis of variance was performed on in vitro digestibility, gas production fermentation kinetics, and in situ degradability data, with browse species as the only source of variation (fixed effect) and source of inoculum (random effect) as a blocking factor. Tukey's multiple comparison test was used to determine which means differed from the rest $(\mathrm{P}<0.05)$. Pearson linear correlation coefficients ( $\mathrm{r}$ ) were determined pairwise between the variables studied. Analysis of variance (PROC MIXED) and correlation (PROC CORR) were performed using the SAS software package (SAS, 2000).

\section{RESULTS}

The forages used in the present study varied substantially in chemical composition (Table 2). The crude protein content was particularly high for F. albida $(252 \mathrm{~g} / \mathrm{kg} \mathrm{DM})$ and lowest for the P. granatum $(109 \mathrm{~g} / \mathrm{kg} \mathrm{DM})$. The cell wall content ranged from 179 to $551 \mathrm{~g} \mathrm{NDF} / \mathrm{kg} \mathrm{DM}$, and from 92 to $273 \mathrm{~g} \mathrm{ADF} / \mathrm{kg}$ DM. In general, the leaves from Acacia spp. showed higher CP and ADL contents than foliage samples from other plant species.

The tannin composition of the plant species is presented in Table 3. Foliage from A. halimus and $F$. albida had the lowest concentrations in total extractable phenolics and total extractable tannins, whereas the highest values were observed in P. granatum. Condensed tannins varied widely among species, being highest in A. nilotica and lowest for A. halimus. Based on the results observed with the PEG bio-assay, the species with greatest tannin biological activity were $A$. nilotica and 

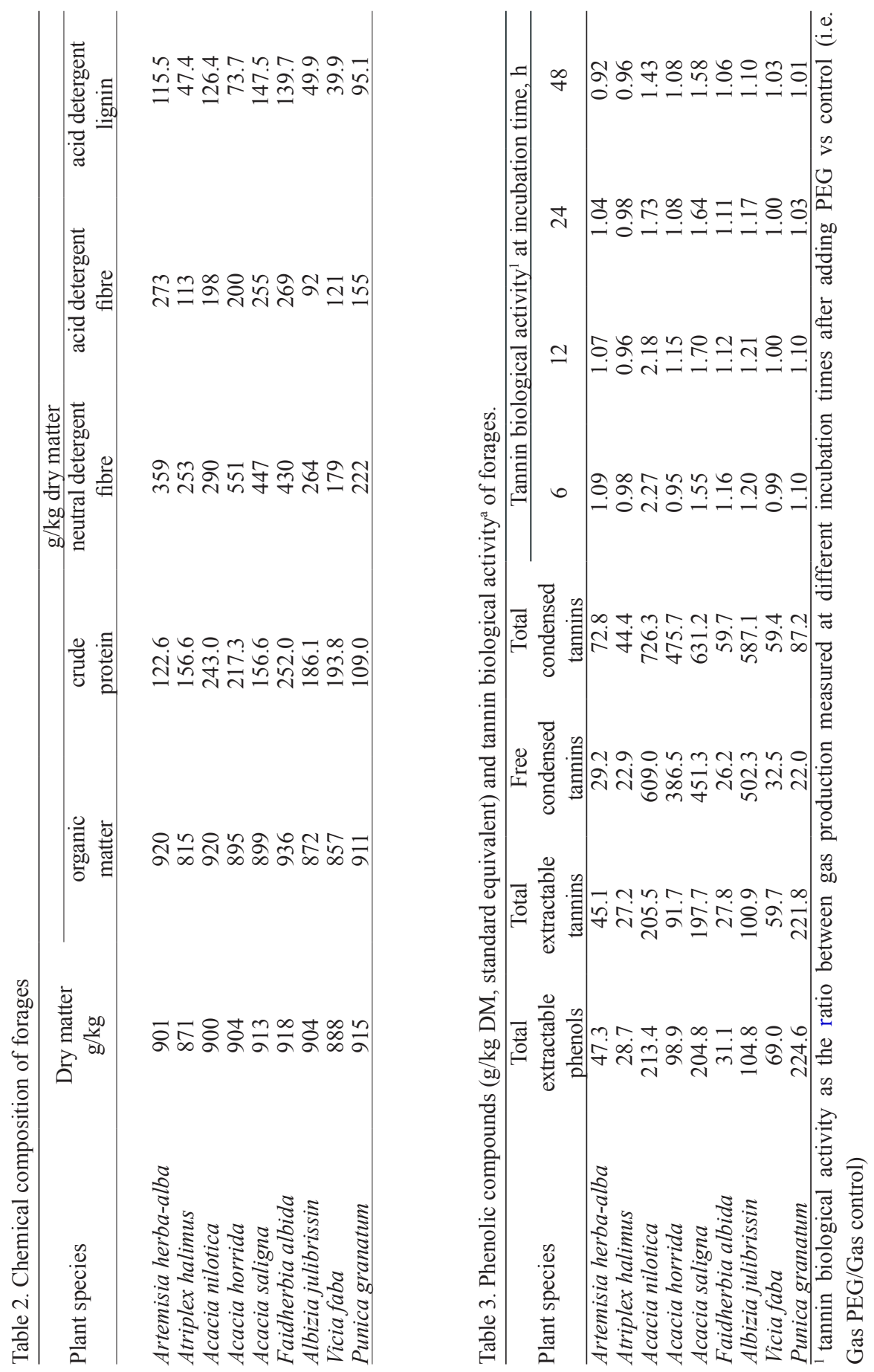

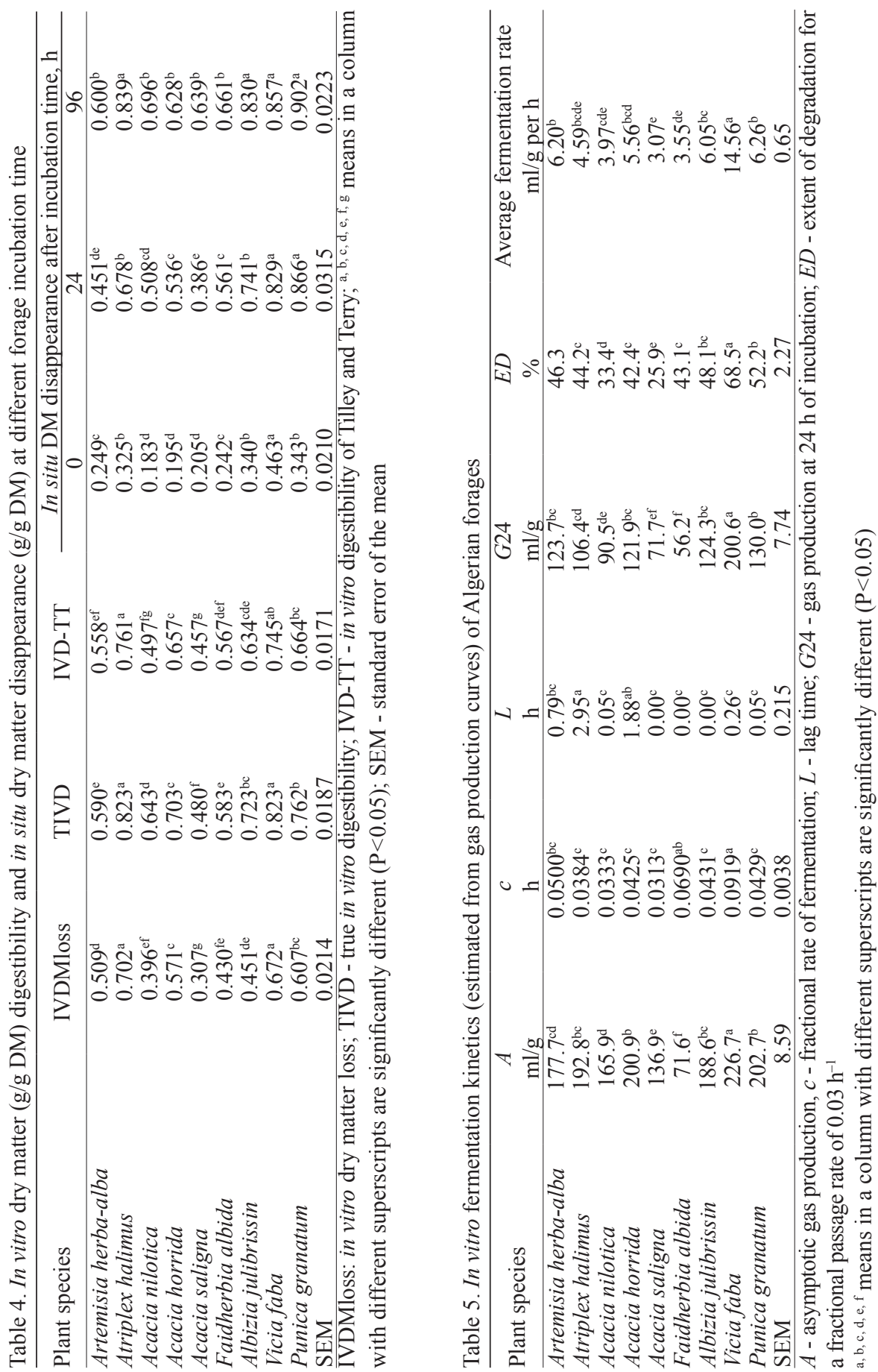
A. saligna (Table 3). Tannin values observed with the different techniques were significantly correlated, and total condensed tannins were positively correlated with tannin biological activity $(\mathrm{r}=0.69, \mathrm{P}=0.03 ; \mathrm{r}=0.80, \mathrm{P}=0.01 ; \mathrm{r}=0.81, \mathrm{P}=0.01$; $\mathrm{r}=0.81, \mathrm{P}=0.01$ at $6,12,24$, and $48 \mathrm{~h}$ of incubation, respectively).

In vitro digestibility and in situ DM disappearance coefficients are shown in Table 4. The most digestible foliage was that from $V$. faba and A. halimus. Intermediate values were found for leaves of $P$. granatum and $A$. horrida, and the lowest in vitro digestibility values were for leaves of $A$. saligna.

Fermentation kinetics parameters are presented in Table 5. Asymptotic gas production (A) and $G 24$ were lowest for F. albida and greatest for $V$. faba. Consistently with in vitro digestibility values, leaves from $A$. saligna showed the lowest rate and extent of rumen degradation (based on parameters $c$ and $E D$ ), whereas the greatest values corresponded to the leaves of $V$. faba.

\section{DISCUSSION}

Artemisia herba-alba is one of the dominant plant species in the shrublands of North African steppes (Le Houérou, 1989). A. herba-alba communities are commonly used as spring pastures by sheep producers. Our results show that this plant has a medium CP content, similar to that reported by El Aich (1992) in Morocco, and slightly greater than values observed for the same plant species collected from Tunisian rangelands (Ben Salem et al., 1994). This plant also showed a low tannin content and medium digestibility.

In dry arid areas, halophytic plants are common in salty soils and produce more biomass than non-halophytic plants. The browsing foliage of A. halimus had relatively high protein and low fibre contents, with low tannin concentrations and high digestibility, in agreement with values reported by other authors (Al-Soqeer, 2008; Ben Salem et al., 2010). The high salt content limits its intake and digestion by ruminants if sufficient water for drinking is not available (Ben Salem et al., 2010).

Foliage from fodder trees and shrubs can be an important feed for livestock in arid areas. The nutritive value of their leaves can be superior to that of herbaceous plants, particularly in the case of leguminous trees (El Aich, 1992; Osuji and Odenyo, 1997). Thus, in the current study the nutritive value of some Acacia species and other fodder tress grown in Algerian steppes was investigated. The CP content of Acacia foliage was relatively high compared with that of the other plant species included in the study (Ben Salem et al., 1997; Al-Soqeer, 2008). The CP content of the browse species studied herein was always higher than the minimum level of 7-8\% DM required for optimum rumen function and feed 
intake in ruminant livestock (Van Soest, 1994). Given the high CP content of the Acacia foliage, this fodder resource can be considered a suitable supplement for poor quality (low N content) natural pastures and crop residues such as straw and stover (Osuji and Odenyo, 1997; Osuga et al., 2007), even though tannins can considerably reduce the extent of protein degradation in the rumen (Makkar, 2003; Alam et al., 2007). The low- to moderate fibre content of Acacia foliage would also benefit voluntary intake and digestibility of poor quality roughage (Osuji and Odenyo, 1997). Foliage from some of the Acacia (A. saligna and F. albida) species had high lignin contents, however, and thus a relatively low digestibility (Rubanza et al., 2005). Compared with the Acacia spp., foliage from P. granatum and A. julibrissin was highly digestible, with low TCT concentrations and, in the case of A. julibrissin, high protein contents.

The concentration of phenolic compounds in the foliage material showed considerable variation among species, with $P$. granatum having the highest concentration of TEP and TET, and foliage from of A. halimus and F. albida having the lowest. These differences may be due not only to plant species, but also to harvest season and plant maturity stage (Makkar et al., 2007). Leaf samples of F. albida were harvested in the late rainy season of May, whereas A. nilotica was harvested in autumn. Furthermore, the considerable variation in plant species ranking observed when considering the different phenolic fractions analysed could be related the method of analysis, as the type and amount of tannins present in each substrate may have a different reactivity with the chemicals used for each method. The lack of accurate laboratory techniques and reliable compounds to be used as standards are major difficulties in the CT analysis. Colorimetric methods should be used with caution as a quantitative assay, as sometimes values obtained are not realistic (e.g., CT $>600 \mathrm{~g} / \mathrm{kg}$, as for A. nilotica). Therefore, differences between our tannin values and others reported in the literature could be due to the nature of the assays used, nature of tannin in different fodder species, standards used for the quantification, plant growth stage, and the influence of soil and climatic factors (Rubanza et al., 2005). Nonetheless, these analytical methods for tannins have received considerable interest as a tool for the comparison and ranking of this sort of roughage. A high proportion of TCT was recovered as FCT, which may be responsible for the possible adverse effects of condensed tannins on microbial fermentation of nutrients in the rumen (Barry and McNabb, 1999). The utilization of CP from Acacia browsable leaves could be limited by their high levels (e.g., $>100 \mathrm{~g} / \mathrm{kg} \mathrm{DM}$ ) of condensed tannins (Abdulrazak et al., 2000). Our high levels of CT in Acacia leaves are in agreement with values reported by other authors (Abdulrazak et al., 2000; Dube et al., 2001; Rubanza et al., 2005). Moreover, the tannin of Acacia has a high protein binding capacity (Alam et al., 2007). The gas production technique coupled with the addition of PEG to neutralize tannins is 
considered an effective tool for determining tannin biological activity (Ammar et al., 2004). The increase in gas production following addition of PEG provides a measure of potential effects of tannins on nutrient degradability (Ammar et al., 2004). Based on these measurements, the species containing tannins with a greatest biological activity would be $A$. nilotica and $A$. saligna. Foliage from these species is also the less digestible compared with other species, demonstrating the detrimental effects on digestion of this fodder. A positive correlation between TCT content and tannin biological activity was observed $(\mathrm{P}<0.001)$, in agreement with other authors (Ammar et al., 2004; Mlambo et al., 2009). Previous studies have shown that condensed tannins can cause a strong depressing effect on ruminal microbial activity and on cellulolytic bacteria (Barry and McNabb, 1999). The biological activity of plant condensed tannins depends on their chemical structure and concentration. The PEG-gas production bio-assay is not intended to quantitate accurately or to characterize the tannins (type and chemical structure) of these phenolic compounds in browse material and animal feedstuffs. It does provide, however, an interesting assessment of the biological effects of tannins depressing ruminal fermentative activity, and allows identification of plant species containing tannins with greater amounts of active antinutritional compounds.

Digestibility of the forage browse samples was determined by two conventional and extensively used in vitro techniques (Tilley and Terry, 1963; Van Soest, 1994), and also assessed from DM disappearance when samples were incubated in situ in the rumen. Differences among browse species in digestibility and gas production parameters can be partly attributed to variations in chemical composition. TIVD and IVD-TT showed significant negative correlations with ADL ( $\mathrm{r}=-0.89 ; \mathrm{P}=0.001$ and $\mathrm{r}=-0.89 ; \mathrm{P}=0.001)$, respectively. NDF and ADF were negatively correlated with in situ DM disappearance after $96 \mathrm{~h}$ of incubation $(\mathrm{r}=-0.84, \mathrm{P}=0.005$ and $\mathrm{r}=-0.86 ; \mathrm{P}=0.003$, respectively). The results also indicate that high levels of condensed tannins in some species may reduce their digestibility by ruminants (Barry and McNabb, 1999; Makkar et al., 2007).

Gas production values show large differences in the fermentation parameters for the substrates studied. Cumulative gas production at $24 \mathrm{~h}$ of incubation was lowest $(\mathrm{P}<0.005)$ in some of the samples with the highest $\mathrm{CP}$ content such as F. albida, A. saligna, and A. nilotica. For the last two Acacia spp., this can be attributed to their high TCT concentrations, as the gas production technique is more sensitive to the presence of tannins in the substrate than other in vitro gravimetric techniques. In other cases, as for $F$. albida, its high protein content may have interfered in the gas production results. As protein is degraded, ammonia released will combine with $\mathrm{CO}_{2}$, so that the amount of gas measured in the headspace is considerably reduced. This effect is more pronounced with protein-rich substrates. Nevertheless, the ranking of the fodder species according to rate and extent of 
degradation estimated from the gas production curves was similar to that observed for digestibility determined by in vitro and in situ gravimetric techniques.

Despite its high-protein content, the high tannin concentrations in Acacia foliage may reduce its feeding value and render these plants of marginal value as animal feed. If properly used, tannins can also be beneficial, protecting feed protein from microbial degradation in the rumen, thus increasing the amount of undegraded protein entering the small intestine (Barry and McNabb, 1999). Makkar et al. (2007) reported on the protection of protein from degradation in the rumen by feeding air-dried $A$. saligna leaves with soyabean meal (offered after consumption of the Acacia leaves), resulting in increased daily gain of lambs by $55 \%$, when compared with lambs offered oaten hay-based diets.

\section{CONCLUSIONS}

In conclusion, foliage from Acacia tree species found in arid areas of Algeria can be considered a protein-rich roughage for ruminants, although its high lignin and tannin content is an important constraint limiting its digestion in the gastrointestinal tract. The leguminous fodder tree, A. julibrissin, showed high protein contents and its foliage was more digestible than that from Acacia spp. owing to its lower tannin content. Foliage from $P$. granatum is not a protein-rich roughage, but it can be considered a highly digestible browse for ruminants. All of this information may be used to define strategies for rational utilization of steppe grasslands, in particular to make decisions about the optimum time to use these fodder trees as a feed resource or as a supplement for grazing animals. It should also be possible to formulate the best combinations of browse or herbaceous plants to provide adequate nutrient supply to the animals with optimum utilization of all of the natural resources.

\section{ACKNOWLEDGEMENTS}

L. Bouazza and S. Boufennara gratefully acknowledge the receipt of a Study and Doctoral Research Abroad Fellowship funded by the Algerian Ministry of Higher Education and Scientific Research to conduct the experimental work of their PhD projects at the University of León (Spain). 


\section{REFERENCES}

Abdulrazak S.A., Fujihara T., Ondiek T., Ørskov E.R., 2000. Nutritive evaluation of some Acacia from Kenya. Anim. Feed Sci. Tech. 85, 89-98

Aidoud A., 1994. Pâturage et désertification des steppes arides en Algérie. Cas de la steppe d'alfa (Stipa tenacissima L.). Paralelo $37^{\circ} 16,33-42$

Alam M.R., Amin M.R., Kabir A.K.M.A., Moniruzzaman M., McNeill D.M., 2007. Effect of tannin in Acacia nilotica, Albizia procera and Sesbania acculeata foliage determined in vitro, in sacco and in vivo. Asian-Austr. J. Anim. Sci. 20, 220-228

Al-Soqeer A.A., 2008. Nutritive value assessment of Acacia species using their chemical analyses and in vitro gas production technique. Res. J. Agr. Biol. Sci. 4, 688-694.

Ammar H., López S., Bochi O., Garcia R., Ranilla M.J., 1999. Composition and in vitro digestibility of leaves and stems of grasses and legumes harvested from permanent mountain meadows at different maturity stages. J. Anim. Feed Sci. 8, 599-610

Ammar H., López S., González J.S., Ranilla M.J., 2004. Comparison between analytical methods and biological assays for the assessment of tannin-related antinutritive effects in some Spanish browse species. J. Sci. Food Agr. 84, 1349-1356

AOAC, 2000. Association of Official Analytical Chemists, Official Methods of Analysis. $17^{\text {th }}$ Edition. Washington, DC

Barry T.N., McNabb W.C., 1999. The implications of condensed tannins on the nutritive value of temperate forages fed to ruminants. Brit. J. Nutr. 81, 263-272

Ben Salem H., Nefzaoui A., Abdouli H., 1994. Palatability of shrubs and fodder trees measured on sheep and dromedaries. 1. Methodological approach. Anim. Feed Sci. Tech. 46, 143-153

Ben Salem H., Nefzaoui A., Ben Salem L., Tisserand J.L., 1997. Effect of Acacia cyanophylla Lindl. foliage supply on intake and digestion by sheep fed lucerne hay-based diets. Anim. Feed Sci. Tech. 68, 101-113

Ben Salem H., Norman H.C., Nefzaoui A., Mayberry D.E., Pearce K.L., Revell D.K., 2010. Potential use of oldman saltbush (Atriplex nummularia Lindl.) in sheep and goat feeding. Small Ruminant Res. 91, 13-28

Dube J.S., Reed J.D., Ndlovu L.R., 2001. Proanthocyanidins and other phenolics in Acacia leaves of Southern Africa. Anim. Feed Sci. Tech. 91, 59-67

El Aich A., 1992. Fodder trees and shrubs in range and farming systems in North Africa. In: Legume Trees and Other Fodder Trees as Protein Sources for Livestock. FAO Animal Production and Health, Paper 102. FAO, Rome, pp. 61-73

France J., Dijkstra J., Dhanoa M.S., López S., Bannink A., 2000. Estimating the extent of degradation of ruminant feeds from a description of their gas production profiles observed in vitro: derivation of models and other mathematical considerations. Brit. J. Nutr. 83,143-150

Le Houerou H.N., 1989. An assessment of the economic feasibility of fodder shrubs plantations (with particular reference to Africa). In: C.M. McKell (Editor). The Biology and Utilization of Shrubs. Academic Press. London, pp. 603-629

Le Houerou H.N., 1992. An overview of vegetation and land degradation in world arid lands. In: H.E. Dregne (Editor). Degradation and Restoration of Arid Lands. International Center for Arid and Semi-Arid Land Studies. Texas Technical University. Lubbock, TX, pp. 127-163

López S., 2005. In vitro and in situ techniques for estimating digestibility. In: J. Dijkstra, J.M. Forbes, J. France (Editors). Quantitative Aspects of Ruminant Digestion and Metabolism. $2^{\text {nd }}$ Edition. CAB International. Wallingford, pp. 87-121

López S., France J., Dhanoa M.S., Mould F., Dijkstra J., 1999. Comparison of mathematical models to describe disappearance curves obtained using the polyester bag technique for incubating feeds in the rumen. J. Anim. Sci. 77, 1875-1888 
Makkar H.P.S., 2003. Quantification of Tannins in Tree and Shrub Foliage. Kluwer Academic Publishers. Dordrecht (The Netherlands)

Makkar H.P.S., Francis G., Becker K., 2007. Bioactivity of phytochemicals in some lesser-known plants and their effects and potential applications in livestock and aquaculture production systems. Animal 1, 1371-1391

Mlambo V., Mould F.L., Smith T., Owen E., Sikosana J.L.N., Mueller-Harvey I., 2009. In vitro biological activity of tannins from Acacia and other tree fruits: Correlations with colorimetric and gravimetric phenolic assays. S. Afr. J. Anim. Sci. 39, 131-143

Osuga I.M., Maindi C.N., Abdulrazak S.A., Nishino N., Ichinohe T., Fujihara T., 2007. Potential nutritive value and tannin bioassay of selected Acacia species from Kenya. J. Sci. Food. Agr. 87, $1533-1538$

Osuji P.O., Odenyo A.A., 1997. The role of legume forages as supplements to low quality roughagesILRI experience. Anim. Feed Sci. Tech. 69, 27-38

Rubanza C.D.K., Shem M.N., Otsyina R., Bakengesa S.S., Ichinohe T., Fujihara T., 2005. Polyphenolics and tannins effect on in vitro digestibility of selected Acacia species leaves. Anim. Feed Sci. Tech. 119, 129-142

SAS, 2000. SAS/STAT ${ }^{\circledR}$ User's Guide, 8.1. $4^{\text {th }}$ Edition. SAS Institute Inc. Cary, NC

Theodorou M.K., Williams B.A., Dhanoa M.S., McAllan A.B., France J., 1994. A simple gas production method using a pressure transducer to determine the fermentation kinetics of ruminant feeds. Anim. Feed Sci. Tech. 48, 185-197

Tilley J.M.A., Terry R.A., 1963. A two stage technique for the in vitro digestion of forage crops. J. Brit. Grassl. Soc. 18, 104-111

Van Soest P.J., 1994. Nutritional Ecology of the Ruminant. Cornell University Press. Ithaca, NY

Van Soest P.J., Roberston J.B., Lewis B.A., 1991. Methods for dietary fiber, neutral detergent fiber, and non starch polysaccharides in relation to animal nutrition. J. Dairy Sci. 74, 3583-3597 